\title{
A crítica da estética idealista como crítica da autonomia estética
}

\section{Bruna F. D. Batalhão, Estudante de graduação (IC)}

\section{Resumo}

A estética idealista tal como foi revista por Peter Bürger em seu livro Crítica da estética idealista (1983), se desenvolveu a partir da intenção de $P$. Bürger em compreender a arte atual. A tese fundamental apresentada no livro é de que alguns dos conceitos da estética idealista, se revistos criticamente, constituiriam o núcleo normativo da "instituição arte".

Crítica da estética idealista, instituição arte, autonomia da arte.

\section{Introdução}

A estética idealista se desenvolveu a partir da tentativa de conceitualizar um processo que, sociologicamente, pode ser verificado como o processo de separação da arte em uma esfera autônoma. A crítica de Peter Bürger à estética idealista é a crítica à ideia de que o processo de autonomização da arte teria consistido apenas no seu da práxis vital, mas que também a ideia de autonomia teria hipostasiado a determinação histórica da arte autônoma. A crítica das categorias da estética idealista (em especial a crítica à categoria do "gênio") evidenciaria, portanto, o caráter contraditório do processo de autonomização da arte.

\section{Resultados e Discussão}

As teorias estéticas embora tenham se desenvolvido como forma de conhecimento de dignidade filosófica, frequentemente aspiraram a um conhecimento supra-histórico de seu objeto, é preciso, porém, que elas sejam analisadas não somente como um desenvolvimento da estética, mas também em relação ao desenvolvimento histórico do próprio objeto destas formas de conhecimento. A crítica que Peter Bürger faz às categorias da estética idealista, em sua busca por

tornar claro o processo de autonomização da arte, acaba por fundamentar crítica e historicamente a arte atual.

\section{Conclusões}

A tese de Peter Bürger de que as categorias da estética idealista evidenciariam o processo de autonomização da arte, fundamenta o processo de autonomia da arte como um processo essencialmente contraditório, mas que acaba por tornar reconhecível o processo pelo qual surgiu a arte tal como a conhecemos hoje: em sua forma autônoma, isto é, em sua dimensão institucional.

\footnotetext{
${ }^{1}$ Bürger, Peter. Crítica de la estética idealista. Madrid: Visor, 1996.

${ }^{2}$ Bürger, Peter. Teoria da vanguarda. São Paulo: Cosac Naify, 2008.
} 